\title{
STENEOTARSONEMUS FURCATUS DE LEON (PROSTIGMATA: TARSONEMIDAE) INFESTING RICE CROPS IN BRAZIL
}

\author{
Denise Navia ${ }^{1}$, Marta A. S. Mendes ${ }^{1}$ and Ronald Ochoa ${ }^{2}$ \\ 1 Embrapa Recursos Genéticos e Biotecnologia, Cx. Postal 02372, 70.770-900 Brasilia, DF, Brasil (e-mail: \\ navia@cenargen.embrapa.br); 2 Systematic Entomology Laboratory, USDA, ARS, PSI, Building 005, BARC-West, \\ 10.300 Baltimore Avenue, Beltsville, Maryland, 20705, USA (e-mail: rochoa@sel.barc.usda.gov).
}

\begin{abstract}
Steneotarsonemus furcatus De Leon is reported for the first time infesting rice crops in the State of Mato Grosso do Sul, Brazil. Symptoms observed on the rice infested plants are spots in leaves, stems, sheaths and grains, and sterile panicles with completely empty grains. Phytopathogenic fungi, Bipolaris oryzae (Breda de Haan) and Pyricularia oryzae Cavara, were detected in infested plants. The source of S. furcatus rice infestation as well as the potential of the mite to spread to other areas of the country and become a major pest of this crop are discussed.

Keywords - Acari, Tarsonemidae, phytophagous mite, phytopathogenic fungi, Oryza sativa L., Brazil.
\end{abstract}

\section{INTRODUCTION}

Steneotarsonemus furcatus De Leon 1956 (Prostigmata: Tarsonemidae) was described from Paspalum sp. (Poaceae) from Coral Gables, Florida, USA. In 1958, it was found on Maranta sp. (Marantaceae) grown in a greenhouse in California, USA. Plants infested with the mite showed leaf distortion and appeared to be stunted (Beer, 1958). In 1981, colonies of S. furcatus were found under the leaf sheaths of Maranta sp. in Apopka, Florida causing considerable damage to the plants as well as to Calathea sp. (Marantaceae), rendering many of the plants unmarketable and necessitating the use of chemical pesticides to control its populations (Denmark and Nickerson, 1981). Since then, S. furcatus has been found infesting coconut in Costa Rica, Cuba, El Salvador, Puerto Rico and Venezuela (Howard et al., 1990; Ochoa et al., 1991; Smiley et al., 1993) and in Malaysia (Sathiamma, 1995). In 1998, the mite was found on coconut fruit in the State of Pernambuco, Brazil (Gondim Jr. and Oliveira, 2001). Navia et al. (2005) observed that the species is widely distributed in Brazil. It has been collected on coconut fruit in the States of Alagoas, Minas Gerais, Rio de Janeiro and Sergipe. Recently, Torre et al. (2005) listed 14 Grammineae host plants of $S$. furcatus in Cuba belonging to Brachiaria, Digitaria, Echinochloa, Eleusine, Oryza, Panicum, Paspalum, Rottboelia and Sorghum. In January 2006 , S. furcatus was intercepted in USA from propogative elephant ear bulbs (Colocasia esculenta L.) arriving from Costa Rica (Ochoa, personal communication).
Steneotarsonemus furcatus colonies develop on the meristematic zone of the fruit, which is covered by the perianth (Ochoa et al., 1991, 1994; Navia et al., 2005). It causes longitudinal necrotic areas on the fruit of infested coconuts (Ochoa et al., 1994; Navia et al., 2005).

Until now, Schizotetranychus oryzae Rossi de Simons (Prostigmata: Tetranychidae) was the only mite reported infesting rice in Brazil. This tetranychid spider mite develops on the inner surface of rice leaves, causing long whitish spots along midribs and has only been observed in the southern region of the country (Rossi de Simons, 1966; Flechtmann, 1985).

\section{MATERIALS AND METHODS}

During the 2004-2005 growing season, there was a 30 to $50 \%$ decrease in the rice production $(77 \mathrm{ha}$, cv. Primavera) in Fazenda Jatobá, in the State of Mato Grosso do Sul, Brazil. The cause of the loss was unknown and it could not be attributed to any of the pests usually associated with rice in the country. Almost all of the rice plants in the infested area showed spots on the leaves, stems, sheaths and grains and sterile panicles with grains without seeds (Fig. 1). Samples of whole rice plants from the infested area were taken for three consecutive weeks and sent to the Laboratory of Plant Quarantine, Embrapa Recursos Genéticos e Biotecnologia, Brasilia, Brazil for analyses to determine the causal agent.

A mycological analysis was conducted using the following methods: 1) Incubation of the leaves and stems 


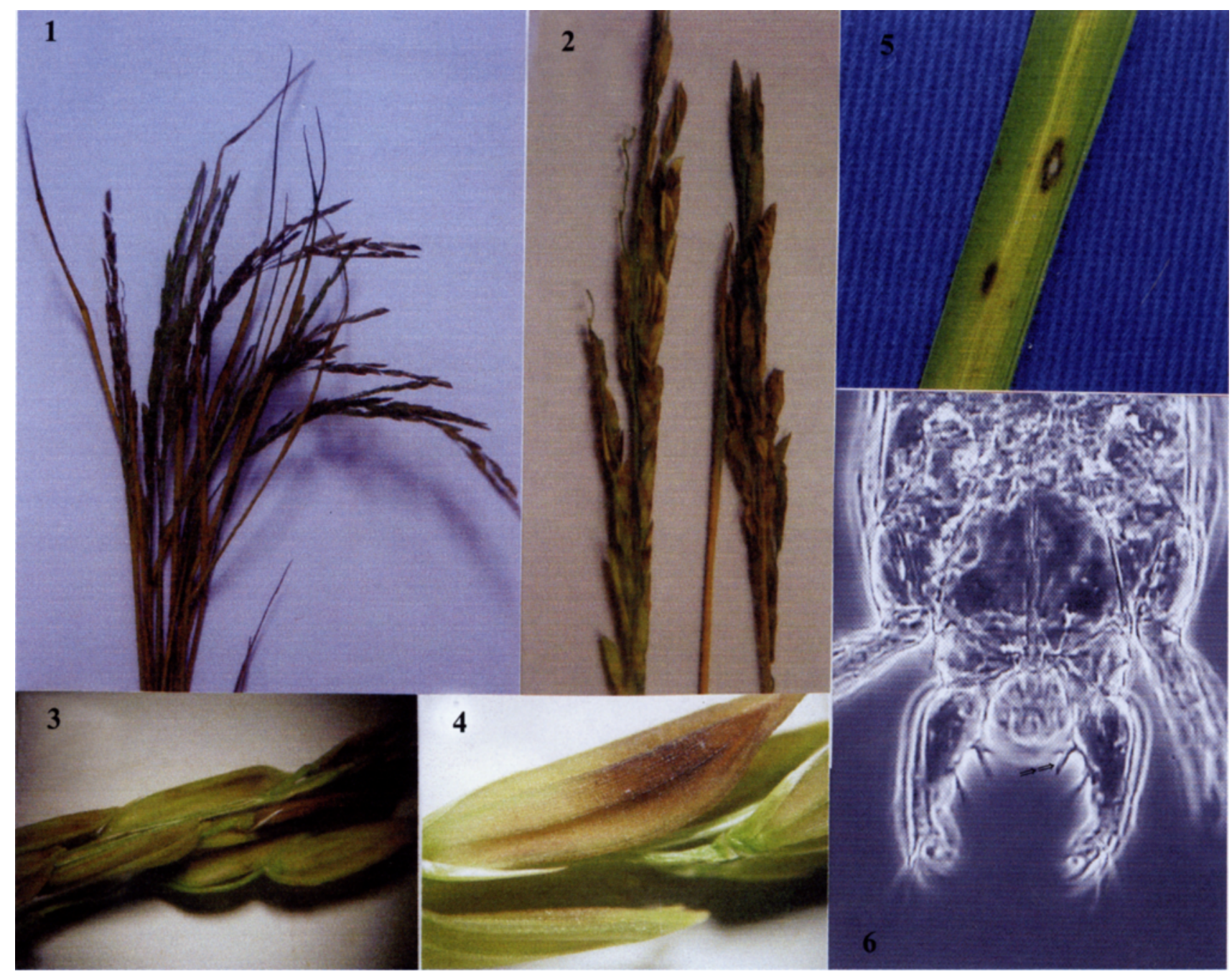

Figs. 1-5. Rice plants infested by Steneotarsonemus furcatus De Leon in State of Mato Grosso do Sul, Brazil - 1. a rice plant, 2. sterile panicle with spotted and empty grains, 3. empty grains under stereomicroscope, 4. detail aspect of spotted grain under stereomicroscope, 5. oval-shaped lesion on a rice leaf caused by Cochliobolus miyabeanus infection, 6 . male of $S$. furcatus showing leg IV with bifurcate V'F seta (see arrow).

in a humidity chamber for three days followed by examination under light microscope for observation of fungal structures; 2) Isolation of vegetation fragments in Potato-Dextrose-Agar (PDA), previously disinfected with $0.2 \%$ sodium hypochloride for 2 minutes and washed twice in sterilized distilled water. The fragments were incubated under continuous fluorescent light at $25-28{ }^{\circ} \mathrm{C}$ for 7-8 days. The fungi were identified using morphological characteristics under the light microscope.

\section{RESULTS AND DISCUSSION}

A large number of tarsonemid mites were detected when plants were examined using a stereoscope microscope (40x). Most of the mites were on panicles but also on leaves, sheaths and stems of the plants (Figs. 1-5). The mites were preserved on microscope slides in Berlese modified medium and identified using a phase contrast microscope. The only phytophagous species found in the samples was identified as Steneotarsonemus furcatus De Leon, 1956 (Fig. 6). The main morphological characters used to distinguish $S$. furcatus from other Steneotarsonemus species were: atrium of main tracheal trunk conspicuously encapsulated, extremely enlarged and ovoid on males and females, and V'F seta on leg IV of the male bifurcate (Fig. 6) (Smiley et al., 1993).

The presence of two main diseases of rice were detected: the brown spot, caused by Cochliobolus miyabeanus (Ito \& Kuribayashi) Drechs. ex Dastur (anamorph: Bipolaris oryzae (Breda de Haan) Shoemaker), and the blast, Pyricularia grisea Sacc. $=P$. oryzae Cavara, (teleomorph: Magnaporthe grisea (Hebert) Barr). These fungi occur in all regions where rice is commercially grown such as Africa, Asia, Central and South 
America, Europe and Oceania, and occurs in all rice-growing areas in the United States (Lee, 1994; Greer et al., 1997). Typical symptoms of brown spot on leaves are oval-shaped lesions of about $1 \mathrm{~cm}$ in length which are evenly distributed (Fig. 5).

Steneotarsonemus furcatus has been collected on rice in China (Ochoa, personal communication), in Cuba (Torre et al., 2005) and in Colombia (ICA, 2005). This is the first record of $S$. furcatus infesting rice in Brazil.

Another species of Steneotarsonemus, S. spinki Smiley, is a noxious rice pest that is known to occur in several Asian countries since the 1930's (Smiley et al., 1993; Cho et al., 1999; Xu et al., 2001; Jagadiswari and Prakash, 2003). It has been disseminated to Central and South America (Colombia) in the last decade (Ramos and Rodriguez, 1998; Mendonça et al., 2004), and is of quarantine concern to Brazil (Brasil, 1999).

Symptoms observed in rice infested with $S$. furcatus in Brazil are similar to those caused by $S$. spinki particularly because both cause panicle sterility and spotted grains (Fig. 4). This similarity emphasizes the importance of properly identifying the species of tarsonemid mites infesting the rice plants to avoid an erroneous diagnosis of the problem. Curiously, in Colombia and Cuba, $S$. furcatus infestations were observed together with $S$. spinki in rice crops (ICA, 2005; Torre et al., 2005).

In Asian and Caribbean countries, infestations of $S$. spinki are associated with an increase in fungal infections by Sarocladium oryzae (Sawada), that causes sheath rot which, together with $S$. spinki, cause panicle sterility, resulting in drastic losses in crop production. The fungus is considered to be an opportunist that causes problems to rice when it is associated with $S$. spinki (Chow et al., 1980; Ramos and Rodriguez, 2003). Evidence suggests that $S$. spinki may carry and disseminate the fungus. Microscopic studies showed the presence of conidia adhering to gnathosomal and cuticular surfaces of $S$. spinki mites; there were no conidia in the digestive tract of the mites, indicating they did not feed on fungus (Chow et al., 1980). Lo and Hor (1977) and Hsieh et al., (1977) also described damage caused by the association of $S$. spinki and the fungus $S$. oryzae. In addition to $S$. oryzae, other species of fungi in the genera Pyricularia, Rhynchosporium and Rhizoctonia are reported with $S$. spinki in Cuba (Almaguel et al., 2003). A similar association may occur between $S$. furcatus infestations and $B$. oryzae and $P$. oryzae infections in rice in Brazil; however, experimental studies need to be conducted to evaluate this hypothesis.

Currently, $S$. furcatus is known to infest a relatively small rice growing area in Brazil. All of the crop residue in the infested area was destroyed in an effort to eliminate the source of infestation. However, due to the proximity of this area to one of the main rice areas of the country (about $200 \mathrm{~km}$ ), in the State of Mato Grosso do Sul (IBGE, 2004), it is possible that it has already spread to other areas and could become a major pest. Therefore, it is important to monitor the areas neighboring the known infestation to detect any new infestations in Brazil.

The origin of the $S$. furcatus population infesting rice in the State of Mato Grosso do Sul, Brazil is unknown. It is possible that populations of $S$. furcatus occurring on coconut shifted to rice as an alternative host. Coconut is widely distributed in Brazil with the main production areas concentrated in the northeastern region; however, small production areas and isolated plants occur throughout the country. Another possible explanation for this mite species dramatic appearance on rice in Brazil may be that it was recently introduced into the country from a rice population, independent of the population that occurs on coconut. Further studies are needed to compare specimens of $S$. furcatus collected on rice versus those collected on coconut to determine the degree of genetic variability that exists between different populations.

\section{ACKNOWLEDGEMENTS}

To Eder Resende Carrijo, Germinex Agropecuária Ltda., MS, Brazil for the rice plant samples and for providing information on the crop area. To Glauce C. P. C. Gonçalves, training at "Laboratório de Quarentena Vegetal, Embrapa Recursos Genéticos e Biotecnologia", Brasilia, Brazil for sample inspection and slide preparation; to Alaide Soares, "Laboratório de Quarentena Vegetal, Embrapa Recursos Genéticos e Biotecnologia", Brasilia, Brazil for helping with the mycological analysis. We are grateful to Drs. Natalia Vandenberg and Douglas Miller, Systematic Entomology Laboratory, ARS, USA, and Greg Evans, APHIS, USDA for their critical reviews of the manuscript and helpful suggestions.

\section{REFERENCES}

Almaguel, L., A. Santos, P. de la Torre, E. Botta, J. Hernández, I. Cáceres and A. Ginarte. 2003.

Dinámica de población e indicadores ecológicos del ácaro Steneotarsonemus spinki Smiley 1968 (Acari: Tarsonemidae) en arroz de riego em Cuba. Fitosanidad, La Habana. 7(1): 23-30.

Beer R. E. 1958. A new species of Steneotarsonemus and additional information on the plant-feeding habits of Steneotarsonemus furcatus De Leon (Acarina). J. New York Ent. Soc. 56: 153-159.

Brasil. Ministério da Agricultura. 1999. Instrução Normativa $n^{\circ} 38$. Lista de pragas quarentenárias A1, A2 e não quarentenárias regulamentadas: alerta máximo. Brasília, DF, Diário Oficial da União. (26 out. 1999, Seção 1)

Cho, M. R., D. S. Kim and D. S. Im. 1999. A new record of tarsonemid mite, Steneotarsonemus spinki (Acari: Tarsonemidae) and its damage on rice in 
Korea. Korean J. Appl. Entomol., Suwon 38(2): 157-164.

Chow, Y. S., S. S. Tzean, C. S. Chang and C. H. Wang. 1980. A morphological approach of the tarsonemid mite Steneotarsonemus spinki Smiley (Tarsonemidae) as a rice plant pest. Acta Arachnol., Osaka. 29(1): 25-41.

Denmark, H. A. and E. Nickerson. 1981. A tarsonemidae mite, Steneotarsonemus furcatus De Leon, a serious pest on Maranta sp. and Calathea sp. (Acarina: Tarsonemidae). Proc. Fla. State Hort. Soc. 94: 7072.

Flechtmann, C. H. W. 1985. Ácaros de Importância Agrícola. (6th ed.) São Paulo, Nobel. 189pp.

Gondim Jr., M. G. C. and J. V. Oliveira. 2001. Ácaros de fruteiras tropicais: importância econômica, identificação e controle. pp. 317-355. In: Michereff, S. J. and R. Barros (Eds.). Proteção de Plantas na Agricultura Sustentável. UFRPE, Imprensa Universitária, Recife.

Greer, C. A., S. C. Scardaci and R. K. Webster. 1997. First report of rice blast caused by Pyricularia grisea in California. Pl. Dis. 81:1094.

Hsieh, S. P. Y., W. L. Liang and S. Y. Chang. 1977. Etiological studies on the sterility of rice plant I. Association of sheath rot fungus, Acrocylidrium oryzae Sawada, with sterile rice plant. Pl. Prot. Bull. (Taiwan). 19: 30-36.

Howard, F.W., E. Abreu-Rodriguez and H.A. Denmark. 1990. Geographical and seasonal distribution of the coconut mite, Aceria guerreronis (Acari: Eriophyidae), in Puerto Rico and Florida, USA. J. Agric. Univ. Puerto Rico 74: 237-251.

ICA (Instituto Colombiano Agropecuário). 2005. Resolución No. 001195 (21 ABR 2005) Por la cual se declara una emergencia fitosanitaria en todo el territorio nacional por la presencia de los ácaros Steneotarsonemus spinki (Smiley) y Steneotarsonemus furcatus (De Leon) en arroz. 4pp. (http:// ww.ica.gov.co/Normatividad/normas/Archivos/200 5R1195.pdf, access 23 oct 2005).

Jagadiswari, R. and A Prakash. 2003. Panicle mite causing sterility in farmer's paddy fields in India. J. Appl. Zool. Res. 14(2): 212-217.

Lee, F. N. 1994. Rice breeding programs, blast epidemics and blast management in the United States. pp 489-500. In: Zeigler R. S., S. A. Leong and P. S. Teng (Eds.). Rice Blast Disease. CAB International, Wallingford, UK, in association with IRRI, Manila, Philippines.

Lo, K. C. and C. C. Hor. 1977. Preliminary studies on rice tarsonemid mite, Steneotarsonemus spinki
(Acarina: Tarsonemidae). Resumo. Rev. Appl Entomol. (Series A, Agricultural). 66(1), Feb. 1978. Article published in National Science Council Monthly. 5(4): 274-284 [in Chinese].

Mendonça, R. S., D. Navia and R. I. Cabrera. 2004. Steneotarsonemus spinki Smiley (Prostigmata: Tarsonemidae): uma ameaça para a cultura do arroz no Brasil. Embrapa Recursos Genéticos e Biotecnologia, Brasília. 48 pp. (Documentos, 117) (http: // www.cenargen.embrapa.br/publica/trabalhos/doc 117.pdf).

Navia, D., G. J. Moraes, A. C. Lofego and C. H. W. Flechtmann. 2005. Acarofauna associada a frutos de coqueiro (Cocos nucifera L.) de algumas localidades das Américas. Neotrop. Entomol. 34(2): 349-354.

Ochoa, R., R. L. Smiley and J. L Saunders. 1991. The family Tarsonemidae in Costa Rica (Acari: Hetero stigmata). Internat. J. Acarol. 17(1): 41-86.

Ochoa R., H. Aguilar and C. Vargas. 1994. Ácaros Fitófagos de América Central: guia ilustrada. CATIE (Centro Agronómico Tropical de Investigación y Enseñanza), Turrialba, Costa Rica, 164 pp.

Ramos, M. and H. Rodriguez, H. 1998. Steneotarsonemus spinki Smiley (Acari:Tarsonemidae): nuevo informe para Cuba. Revista de Protección Vegetal., Havana 13(1): 25-28.

Ramos, M. and D. Rodríguez. 2003. Análisis de riesgo de una especie exótica invasora: Steneotarsonemus spinki Smiley. Etudio de un caso. Rev. Protec. Veg., Havana. 18(3): 158-158.

Rossi de Simons, N. H. 1966. Descripción de Schizotetranychus oryzae sp. n. (Acari - Tetranychidae). Rev. Inv. Agropec, INIA, Serie 5, Patol. Veg. 3(1): $1-10$.

Sathiamma, B. 1995. World distribution of acarine fauna on the coconut palm. Ind. Coconut J. 26: 7-11.

Smiley, R. L., C. H. W. Flechtmann and R. Ochoa. 1993. A new species of Steneotarsonemus (Acari: Tarsonemidae) and an illustrated key to grass-infesting species in the Western hemisphere. Internat $\mathrm{J}$. Acarol. 19 (1): 87-93.

Torre, P. de la, L. Almaguel, E. Botta and I. Cáceres. 2005. Plantas hospedantes de Steneotarsonemus furcatus De Leon (Acari: Tarsonemidae) en Cuba. Neotrop. Entomol. 34(3): 517-519.

$\mathrm{Xu}$, G. L., H. J. Wu, Z. L. Huan, G. Mo and M. Wan. 2001. Study on reproductive characteristics of rice mite, Steneotarsonemus spinki Smiley (Acari: Tarsonemidae). Syst. Appl. Acarol. 6: 45-49. 